
(2021). The Impact of Celebrity Endorsement of Sporting Goods on Consumer Purchasing Behavior.

ISSN: 2526-7884

Editor: Prof. Dr. Marconi Freitas da Costa

E-mail: cbr@ufpe.br
Evaluation: Double blind review

Received: July 10, 2021

Approved: August 11, 2021

\title{
THE IMPACT OF CELEBRITY ENDORSEMENT OF SPORTING GOODS ON CONSUMER PURCHASING BEHAVIOR
}

O impacto do endosso de artigos esportivos por celebridades no comportamento de compra do consumidor

\author{
Vahidreza Mirabi ${ }^{1}$ \\ ORCID: https://orcid.org/0000-0003-2861-7494 \\ E-mail:vrmirabi@yahoo.com \\ Fariba Fathi ${ }^{1}$ \\ ORCID: https://orcid.org/0000-0002-4600-7406 \\ E-mail: faribafathi509@gmail.com \\ Mohammad Fotouhi Ardakani² \\ ORCID: https://orcid.org/0000-0002-6921-2082 \\ E-mail:m.fotoohi90@yahoo.com \\ Razieh Khojasteh Avorgani ${ }^{2}$ \\ ORCID: https://orcid.org/0000-0003-4379-7892 \\ E-mail: raziehkhojasteh2000@gmail.com \\ ${ }^{1}$ Islamic Azad University, Tehran, Iran \\ ${ }^{2}$ Ardakan University, Ardakan, Iran
}

\begin{abstract}
The aim of this research is examine the impact of celebrity endorsement of sports goods on customer purchasing behavior, and to compare
\end{abstract}

Resumo
O objetivo desta pesquisa é examinar o
impacto do endosso de celebridades a
produtos esportivos no comportamento de
compra do cliente e comparar a eficácia dos

Resumo

0 objetivo desta pesquisa é examinar o impacto do endosso de celebridades a compra do cliente e comparar a eficácia dos 
the effectiveness of the relevant components at different ages. The research is applied in terms of objective, and it is exploratory-survey in terms of methodology, and data collection was done through questionnaire and field methods. The target statistical population includes all residents of Mashhad, which are totally more than 3 million. In the present research, given the attributes of the statistical population, twostage cluster sampling method was chosen. In this method, every citizen of Mashhad was considered a sample unit. In this research, the effects of celebrity endorsement are considered as predictor variable, and the relevant dimensions include celebrity availability, validity, credibility, physical attractiveness, popularity, motivation, nationality, fame, celebrity-consumer match, celebrity personality and lifestyle, celebrity's use of brand, and celebrity-product compatibility. In the research, consumer purchasing behavior is the criterion variable. Following the hypothesis testing, the article comes to the conclusion that some components influence consumer behavior, and the impact of various factors on age, gender, and different educational levels are investigated as well.

Keywords: Celebrity Endorsement of Product; Customer Purchasing Behavior; Influential Components at Different Ages. componentes relevantes em diferentes idades. A pesquisa é aplicada em termos de objetivo, trata-se de um levantamento exploratório em termos de metodologia, e a coleta de dados foi feita por meio de questionário e métodos de campo. A população-alvo estatística inclui todos os residentes de Mashhad, que são no total mais de 3 milhões. Na presente pesquisa, dados os atributos estatísticos da população, optou-se pelo método de amostragem por conglomerados em dois estágios. Nesse método, todo cidadão de Mashhad foi considerado uma unidade amostral. Nesta pesquisa, os efeitos do endosso de celebridade são considerados como variáveis de previsão, e as dimensões relevantes incluem disponibilidade de celebridade, validade, credibilidade, atratividade física, popularidade, motivação, nacionalidade, fama, compatibilidade celebridade-consumidor, personalidade e estilo de vida de celebridade, uso de celebridade de marca e compatibilidade de produtos de celebridades. Na pesquisa, o comportamento de compra do consumidor é a variável de critério. Após o teste de hipóteses, o artigo chega à conclusão de que alguns componentes influenciam o comportamento do consumidor, e o impacto de vários fatores sobre a idade, sexo e diferentes níveis educacionais também são investigados.

Palavras-chave: Endosso de produtos de celebridades; Comportamento de compra do cliente; Componentes influentes em diferentes idades.

\section{INTRODUCTION}

Nowadays, advertising and marketing have been developed to the extent that they have turned into one of market management processes. Advertisement positively can supply people with their required good, and negatively may introduce the goods and services that society does not need in such a way that people feel the goods and services offered are basic and required. Thus, advertisement sometimes meets the real needs of the individual, and sometimes even introduces to people a hidden and unnecessary need to the extent that one feels if he fails to have the product, his social personality will hurt. Accordingly, advertising and marketing can positively turn perceived needs into real ones, and aspirational needs into motivational ones, and even reveal hidden needs. Advertisement is a type of message, and media given its nature can convey such type of message to its target audience. How to convey the message can significantly determine the impact of advertising on consumer behavior, such that if celebrity endorse the relevant goods and services, people become more willing to purchase the advertised product (Memar Nejad, 2012). 
The consumer is the one who pays the money to consume the goods and services, which are produced by the companies. We all come into this category and we consume things according to our needs, preferences and buying power. There are many kinds of goods including consumable goods, durable goods, specialty goods, and industrial goods. Consumer behavior depends on many factors like what we buy, how we buy, where and when we buy, in how much quantity we buy which is based on our perception, self-concept, social and cultural background and our age and family cycle, our attitudes, beliefs, values, motivation, personality, social class and many other factors that are both internal and external to us (Arora \& Sahu, 2014).

The behavior of individuals depends on their thoughts, beliefs, and attitudes, and any change in behavior requires an initial change in attitude. Accordingly, attitudes are the most important determinants of behavior. Concepts such as beliefs, attitudes and behavior are strongly related to each other. General term 'consumer attitudes formation' is often used to describe the relevant area. In fact, in the field of consumer behavior, the issue that has been highly researched and discussed more than any other relevant topic is consumer attitude (Saffarinia \& Karimi, 2005).

Today, the consumption pattern of the consumers and their behavior is gradually changing. New demands, technology, lifestyle and acceptance of other countries' cultures are forcing companies to do continuous change in their offers and promotions. Hence, promotion can bring a large part of foreign business and international markets (Alamolhodaei \& Ardakani, 2015).

Increased competition favors the consumer to get more variety and quality in reasonable price. Nowadays, consumers play an important role in the economic system of many countries. Every brand attempts to find at least a fraction of an audience's time to inform him or her of the various unique attributes of the products at hand. Due to the constant flooding of the standard marketing campaigns by various media, the audience eventually become insensitive towards them. Hence, now-a-days marketers are facing challenge to find out the ways that will gain the attention of the consumer. Nowa-days, many companies are signing contracts with celebrities in the expectation that by using celebrities they can achieve a unique and appropriate position in the minds of the customers (Arora \& Sahu, 2014). Celebrities are the personalities that are well known in public either because of their credibility or of their attractiveness or because of both. To leverage this, advertisers use celebrities in their advertisement to increase the effectiveness and heighten the believability of commercials (Ahmed et al. 2012).

Today, celebrity endorsement is being seen as a more and more essential part in an integrated marketing communication strategy. Every marketer aspires to use it. However, there is also a great risk behind the use of the celebrities .The celebrity should be match with personality of the products, personality of target market and with the society. Today, the attitude, taste, preferences and buying pattern of consumers are changing rapidly and consumers are becoming more literate and aware of the products that they use to fulfill their needs and wants. Today, celebrity endorsement is a very successful and commonly practiced strategy for major firms to create and improve company's brand image (Arora \& Sahu, 2014).

\section{LITERATURE AND RESEARCH BACKGROUND}

Attitude: Attitude is a central part of human individuality. Most of people because of their beliefs and attitudes even lose their lives. Attitude is a durable system that includes a cognitive element, an emotional element, and a willingness to act (Saffarinia \& Karimi, 2005). Consumer attitude is divided into three components including cognitive dimension (i.e. consumer beliefs), affective dimension, and behavioral dimension. Individuals in a society always act in harmony with their attitude (Saffarinia \& Karimi, 2005).

Patterns of attitude formation and change: although some aspects of change in attitude may be exaggerated, at least under certain circumstances, preferences could lead to new practices of behavior. Change in attitude through classic conditioning: it is presentation of a stimulant consistent with one of the responses of the organism. In advertisement, some elements such as beautiful scenery, 
lively music, popular athletes, and attractive actors must be used to lead to change in customer attitude.

Change in attitude through proactive conditioning: the principles of proactive conditioning dictates that the behavior of a living being is repeated when it is reinforced. In 1950, a team of social psychologists led by Hovland et al. (1949) presented a model to change the attitude. To their view, there are three significant variables in learning new attitudes including attention, understanding, and acceptance. The team specified the factors affecting the reception of a persuasive message. To summarize these factors, usually the phrase "Who says what to whom?" is used. Some of the variables that Hovland et al. (1949) and his team studied include:

\section{Message Source}

In most cases, the source of a message can have a great impact on the likelihood of its adoption by the recipients. Select a source for maximizing change in attitude encompasses several dimensions. Credibility and attractiveness are two main characteristics of the source. There must be a consistency between the needs of the recipient and potential rewards provided by the source. For example, an attractive or beautiful source is more effective on those who are more sensitive to social approval and others' views. In contrast, a credible and expert source, when associated with introverts, is more powerful (Solomon, 2014).

Source Credibility: The credibility refers to the expertise, objectivity, and reliability of a transmitter. Honesty and credibility are of particular significance especially when the company aspires to advertise its corporate social responsibility activities in a way to benefit the community. Therefore, reliability have positive impact on customer satisfaction (Ardakani et al., 2015).

A credible source is especially when encouraging that consumers still do not know much about the product or have not presented comment on it (Solomon, 2014). The Source Credibility Model holds that effectiveness of a message is based on the perceived level of expertise and trustworthiness the customers have in an endorser (Sternthal et al., 1978). Expertise can be defined as the extent to which the endorser (communicator) is perceived to be knowledgeable, skillful and experienced. And the statements it makes turn out to be valid. The main benefit in using expert endorser is that it enhances brand recall and positively affects the buying intentions of consumers (Erdogan, 1999).Trustworthiness can be defined as the extent to which the endorser is perceived to be believable, honest and dependable. Greater the proportion of these aspects, higher will be the likelihood of the endorser to be selected by the advertisers (Shimp, 2008).

The message transferor may be important as much as the message itself. In this context, some factors including the messenger's popularity, compatibility, attractiveness, and power have been underlined in different research. In fact, two factors including acceptance and compatibility can turn a message source into an effective one in conveying their message.

Acceptability: Why a medical journal that provides readers with some information on AIDS is considered more acceptable than another journal or a drug dealer that reports the same information? This issue depends on two factors related to the acceptability: competence and trustworthiness. It can be concluded that the public accept experts' statements without thinking deeply about it (Saffarinia \& Karimi, 2005).

Compatibility \& attractiveness: According to the research carried out in this area of study, two factors that can affect others include physical attractiveness and compatibility of messenger. Identification with the person who aims to convince us is also of importance. When we accept someone's point of view, we share his ideas, and share our beauty with him (Saffarinia \& Karimi, 2005).

Source Attractiveness and Celebrities: Source attractiveness is a social value which recipients ascribe it to a transmitter. This value is concerned with physical landscape, personality, social status, or 
similarity to the recipient (we are naturally predisposed to listen the people that are like us). One study showed that our brains tend to pay more attention to the celebrities and to process the information relevant to them more efficiently than normal people. Celebrities increase awareness to a firm and reinforce corporate image and brand attitudes.

The main reason for the efficiency of celebrities' power is that this special group of people encompasses cultural meanings, and they represent important categories such as the status and social class, and so on (Solomon, 2014). Celebrities are considered as an example of intellectual and opinion leaders, and in the form of a reference group have the ability to direct preferences of consumers toward a specific product or brand (Solomon, 2014) Therefore, the interests and tastes of the customers can play an important role in the development of marketing and achieving success in this regard (Abdolvand \& Hoseinzadeh Emam, 2014). Attractiveness doesn't solely mean physical attractiveness; instead it encompasses lifestyle of the endorser, its personality dimensions.

According to McGuire (1968), three factors contribute to the effectiveness of message. These are familiarity of an endorser, similarity of an endorser and liking of an endorser. Similarity can be defined as the extent to which the receiver (customer) finds resemblance between itself and the source (endorser). Familiarity refers to that how much knowledge the receiver (customer) possesses about the source (endorser). And likability is the affection the receiver (customer) develops towards source (endorser) because of the physical attractiveness of the endorser (McGuire, 1968). It is quite evident that customer form positive and favorable perceptions about those endorsers who are physically attractive (Erdogan, 1999). Research findings show that attractive endorsers are good at influencing the beliefs of customers (Debevec \& Kernan, 1984). That is why most of the advertisements depict attractive celebrities (Baker \& Churchill Jr. 1977). This presents the advertisers with the twofold benefits of celebrity presence and physical plea (Erdogan, 1999).

\section{Message}

The research performed by Hovland et al. (1949) suggest that the choice of strategy depends on the relevant population. Those who are less well educated, are not very familiar with the subject or thought discussed, or have been less emotionally involved, accept emotional messages more promptly. In contrast, the people well knowledgeable on the advertising field become more easily convinced when they are provided with sufficient justifications (Saffarinia \& Karimi, 2005).

\section{Message sender or listener}

Message content and style must be proportionate to message receivers. The research performed show that the messages sent by the media are able to significantly impact attitudes and behavior of consumers (Rajesh et al., 2019). Another major characteristic in this context is age. People's opinion will remain constant in adulthood. In a research performed by Doan Alvin (1982) on the study of political attitudes collected from 2500 Americans in three different times, each message for having effectiveness should be carefully recognized and then accepted by the audience. Therefore, in the case of educated people and the ones with higher mental ability and strong understanding, a message needs to be very convincing. Intelligent people do not accept ideas very simply.

\section{Observational learning}

Observational learning was developed by Albert Bandura, yet he makes a distinction between observational learning and mere emulation of behavioral pattern. Observational learning may include imitation or not. Three major ideas emanate from observational learning (Hergenhan and Olson, 2005).

A) Observational learning theorists regard people as symbolic beings that are able to predict the possible outcomes of their behavior. People anticipate the future and modify their behavior accordingly.

B) People have the ability to regulate their own behavior, and through self-regulatory, self-critical or self-appreciative processes, they internally punish or reward themselves. 
C) By observing the actions of others and relevant consequences, people can achieve learning. Social learning theorists in particular have underlined the importance of the models in the transfer of information through observational learning (Shahbazi, 2012).

A model is someone that somebody else aims to emulate his behavior as an exemplar. It has been shown that the effectiveness of a model can be promoted via the following factors (Mowen \& Minor, 2002): (1) Physical attractiveness; (2) Credibility; (3) Success; (4) Consistency between the model and promoter; (5) Ability to overcome the problems and then acting as a successful model.

\section{Celebrity Endorser}

According to McCracken (1989), a celebrity endorser is defined as "any individual who enjoys public recognition and who uses this recognition on behalf of a consumer good by appearing with it in an advertisement (Wei \& Lu, 2013). According to (Schlecht, 2003) term 'celebrity' can be defined as "the people who enjoy public recognition by a large share of certain group of people" (Ahmed et al. 2012).

\section{The Product Matchup Hypothesis}

The Product Match-Up Hypothesis states that there should be perfect match between the celebrity personality characteristics and brand attributes. The extent of successful match-up can be determined by the degree of fitness between the brand and the celebrity (Erdogan, 1999). An advertisement in which the celebrity and the brand are highly congruent yields to be more influential and believable (Ahmed at al., 2012). Today companies are exerting great emphasis upon the importance of proper match-up between the celebrity and the product. Whether it's a beverage company or any other, companies always look eager for a fitting link between celebrity's personality and product attributes. This also happens on the part of customers as they also expect congruity between celebrity and the product (Ohanian, 1991). The product celebrity match-up doesn't solely rely on just ordinary congruency but on the physical attractiveness of the celebrity as well. Attractive celebrities are more persuasive specially when endorsing the products that enhance the prettiness, because customers assume that as the product enhanced the beauty of the endorser, so does it will in real (Kamins, 1990). Another study revealed that only those celebrities should endorse who are congruent and perceived by the customers to have expertise as well (Ohanian, 1991).

\section{The Elaboration Likelihood Model}

According to The Elaboration Likelihood Model, two key ingredients, motivation and ability serve as the basis of elaboration likelihood. Motivation to perceive the message comprises being involved and relevancy whereas ability is based on knowhow of the individual and analytical capability to perceive and process the persuasive message. The Elaboration Likelihood Model suggests two paths i.e. Central Route and Peripheral Route that lead to attitude change. According to the Central Route, the customer actively pays attention to the advisement and the customer level of involvement is high. Now this persuasion of advertisement may lead to either favorable response or unfavorable response by the customer which ultimately results into development of lasting positive and negative attitudes. According to the Peripheral Route, the receiver is not actively involved and thus lacks motivation. It just perceives and evaluates the advertisement on secondary cues. Eventually, the attitudes the receiver forms (favorable or unfavorable) about the message are temporary (Ahmed et al. 2012).

\section{Celebrities and Consumers Behavior}

The issue of celebrity endorsement in advertising has received significant attention in the literature. Many studies show strong support for the use of celebrity endorsements, arguing that celebrities can make brands recognizable and create a positive brand attitude (Petty et al., 1983), enhance the likelihood of purchase (Friedman \& Friedman, 1979), foster brand loyalty, and positively impact word-of-mouth (Bush, Martin, \& Bush, 2004). Hoffner and Cantor (1991) also point out that 
people emulate the appearance and behavior of the media celebrities that they admire. Advertisers often employ celebrities to endorse a product to enhance audience attentiveness, add glamour and desirability to the product, and make the advertisement more memorable and credible (Spielman, 1981). Scholars have shown that using famous celebrities to endorse products is generally more effective than using non-celebrities to generate positive responses from consumers (Atkin \& Block, 1983).

Today, new marketing concepts are increasingly applied in advertisement, and the use of effective propaganda tools to support and influence the perception of brand mother is increasingly expanding. One of the specific propaganda instruments is utilization of distinguished figures and celebrities who are desirable for the audience from several perspectives including accreditation, persuasion and provocation, creation of a sense of confidence and credibility. In other words, by ascribing their own image, credibility, reputation, character, and generally brand to a product, celebrities as endorser and guarantor increase the awareness of the audience, encourage them, influence their buying decision and finally raise income level. Thus, use of celebrities and famous personalities in order to create value for goods provides organizations and firms with various consequences because of the celebrities' enjoyment of cultural and professional backgrounds, age and social acceptability. Famous personalities take privilege of quality and values that are cherished and respected by others. In other words, having different characteristics to social norms such as unique lifestyle, and individual charm, celebrities have special skills to attract the attention of others in the category to which they are entering (Abdolvand \& Hoseinzadeh Emam, 2014).

Celebrity endorsement has been long in application (Kaikati, 1987), in fact not too late when advertisement techniques were taking on new forms because advertisers realized soon that by using publicly renowned personalities in advertisements they will be able to align brands personalities with that of the celebrity's. Moreover, these credible endorsers can produce more favorable attitudes toward the advertisement (Goldsmith et al., 2000) and intent to purchase the product (Wei \& Lu, 2013).

\section{Reference Group}

According to Solomon (2014), reference group is the one whose attitudes or values are used by an individual as the basis for behavior. Reference group is the one which its values, norms, attitudes or beliefs is used as a guide to individual behavior (Mowen \& Minor, 2010). An individual's reference groups are composed of all the groups that can influence his beliefs and behavior either directly or indirectly. The groups that directly affect the person are called membership groups (Kotler, 2006). Reference groups can have three types of effect on people. Information effect occurs when a person applies behavior and attitude of the members of the reference group as useful data elements. Prescriptive effect which is also called utilitarian effect is said to occur when a person meets group's expectations by earning direct reward or by avoidance of punishment. The cognitive effects occur when people apply perceived norms and values in the group as a guide to their attitudes and values (Solomon, 2014). Reference groups influence people through the norms, information and valueoriented demonstrative needs of consumers (Mowen \& Minor, 2010). One instance of such groups is celebrities that are admired by the community because of their reputation, popularity, fame and other achievements, and firms use these individuals and organizations to encourage consumers to buy their goods (Abdolvand \& Hoseinzadeh Emam, 2014).

\section{A Review of Research}

Most studies on celebrity endorsers have explored how the credibility of the source affects the success of the message. A highly credible source is more persuasive than a less credible source in influencing audience attitudes and behavioral intentions (Sternthal al., 1978). Ohanian (1991) has synthesized the previous literature on this subject and proposed three distinct dimensions of celebrity endorser credibility including expertise, trustworthiness, and attractiveness. (Wei \& Lu, 2013).

Gresham and Shimp (1985) said that the primary issue for advertising theory and research is one of chosen structured processes by which the consumers' attitudes and behavior intentions are 
affected by approach toward the ads making(Arora \& Sahu, 2014). On the concept and application of celebrity endorsement, Agrawal and Kamakura (1995) cite industry sources who guess that approximately $20 \%$ of all TV commercials feature famous people. Assured sets of products feature celebrity endorsements more frequently. They studied every endorsement contract since 1980 to 1992.

Experiments proposed that, in few situations, celebrity endorsement could improve recall and consume evaluation of the products (Adam \& Hussain, 2017). According to Ataman and Ulengin (2003), the relationship between the consumer and the brand will only the strengthened when the consumer's own physical and psychological needs and the brand's functional attributes and symbolic values as perceived by the consumer. As there are four roles of customers (initiator, influencer, buyer and user). Here there is a need to find that which of the roles are more affected by celebrity endorsement (Arora \& Sahu, 2014).

Ohanian (1991) investigated the relationship of attractiveness, trustworthiness, and expertise with the intention of purchase and found that only the perceived expertise of a celebrity as a significant factor is able to generate more intentions of buying any brand. The author suggests that a celebrity spokesperson should be very effective. According to him, a celebrity should be knowledgeable, experienced and qualified to talk about the product. Ohanian states, "no matter whether an endorser is an expert or not; all that matters is how the target audience perceives the endorser". The researcher indicated that when a perceived expert delivers the message adds the credibility to the message and influences the purchase behavior of the customer.

Attractiveness refers to how physically attractive, elegant, or likable the source is to the audience. Therefore, endorsers who are perceived to be knowledgeable, reliable, and attractive are considered credible and, in turn, induce consumers' positive attitudinal and behavioral responses to the brand and the product (Ohanian, 1991; Wei \& Lu, 2013). Advertisers try to hire such celebrities for endorsement who are not only attractive (Baker \& Churchill Jr. 1977) but credible as well (Sternthal et al., 1978).

Ahmad et al. (2012) in a study entitled "The impact of celebrity endorsement on customer buying behavior: a perspective from Pakistan" which was performed at the University of Pakistan, investigated the impact of celebrity endorsement on customer purchase intention by taking five models into account including Source Attractiveness Model, Source Credibility Model (celebrity endorsement), Product Match-Up Hypothesis, Meaning Transfer Model, Elaboration Likelihood Model, and came to the conclusion that: Advertisements are always designed to attract greater attention of the audience.

Wei and Lu (2013) in a study entitled "Effect of celebrities and customer online reviews on customer buying behavior of female clients compared the impact of the presence of celebrities and the process of "customer online reviews" on the buying behavior of female clients, based on models and AIDMA (Attention, Interest, Desire, Memory, and Action) AISAS (Attention, Interest, Search, Action and Share) and the combination of these two models.

\section{Research objectives and hypotheses}

The current article seeks to examine the effect of celebrity endorsement on customer purchasing behavior and to compare the effectiveness of its components on demographic indicators. Therefore, in this study, the effect of celebrity endorsement is regarded as predictor variable, and its relevant dimensions include:

1-Celebrity availability

2-Validty of celebrity

3-Crediblity

4-Physical attractiveness

5-Celebrity-product match

6-Popularity

7-Celebrity-consumer compatibility 
8-Persoanlity and life style of celebrity

9-Motivating impacts of celebrity on customer purchasing behavior

10-Celebrity's use of the brand

11-Nationality of celebrity

12-Fame of celebrity

Criterion variable: in the current research, the consumer purchasing behavior is regarded as criterion variable.

\section{Research hypotheses}

1) The celebrity availability in sporting goods advertising can influence consumer purchasing behavior.

2) The validity of celebrity in adoption of sporting goods advertising can be effective on consumer purchasing attitude.

3) Credibility of celebrity in adoption of sporting goods advertising can influence consumer purchasing attitude.

4) Attractiveness of celebrity in adoption of sporting goods advertising can influence consumer purchasing attitude.

5) Celebrity-product match in adoption of sporting goods advertising can influence consumer purchasing attitude.

6) Popularity of celebrity in adoption of sporting goods advertising can influence consumer purchasing attitude.

7) Celebrity-consumer compatibility in adoption of sporting goods advertising can influence consumer purchasing attitude.

8) Personality and life style of celebrity in adoption of sporting goods advertising can influence consumer purchasing attitude.

9) Motivating impacts of celebrity in adoption of sporting goods advertising can influence consumer purchasing attitude.

10) Celebrity's use of brand to in adoption of sporting goods advertising can influence consumer purchasing attitude.

11) Nationality of celebrity in adoption of sporting goods advertising can influence consumer purchasing attitude.

12) Fame of celebrity in adoption of sporting goods advertising can influence consumer purchasing attitude.

\section{Research methodology, conceptual framework, and research model}

The conceptual framework is basis for conducting studies and demonstrates a form of the relationship between the dependent and the independent variables (Danai et al., 2018). This theoretical framework is based on theoretical relationships among a number of factors that are considered significant in the area and presents a research background of the issue under study in the current research, and the main subjects continue to be discussed in detail as below.

Mukherjee (2009) presents 20 prominent and effective attributes of celebrity endorsement. By combining Ardakani et al (2015) and Mukherjee (2009) model and customer attitudes and preferences by Christine (2011), a conceptual model is offered. In the present study, 12 attributes of Mukherjee's model are tested, and then the impact of these components on demographic criteria such as age, sex, occupation, education, and marital status of the population are tested and compared. 


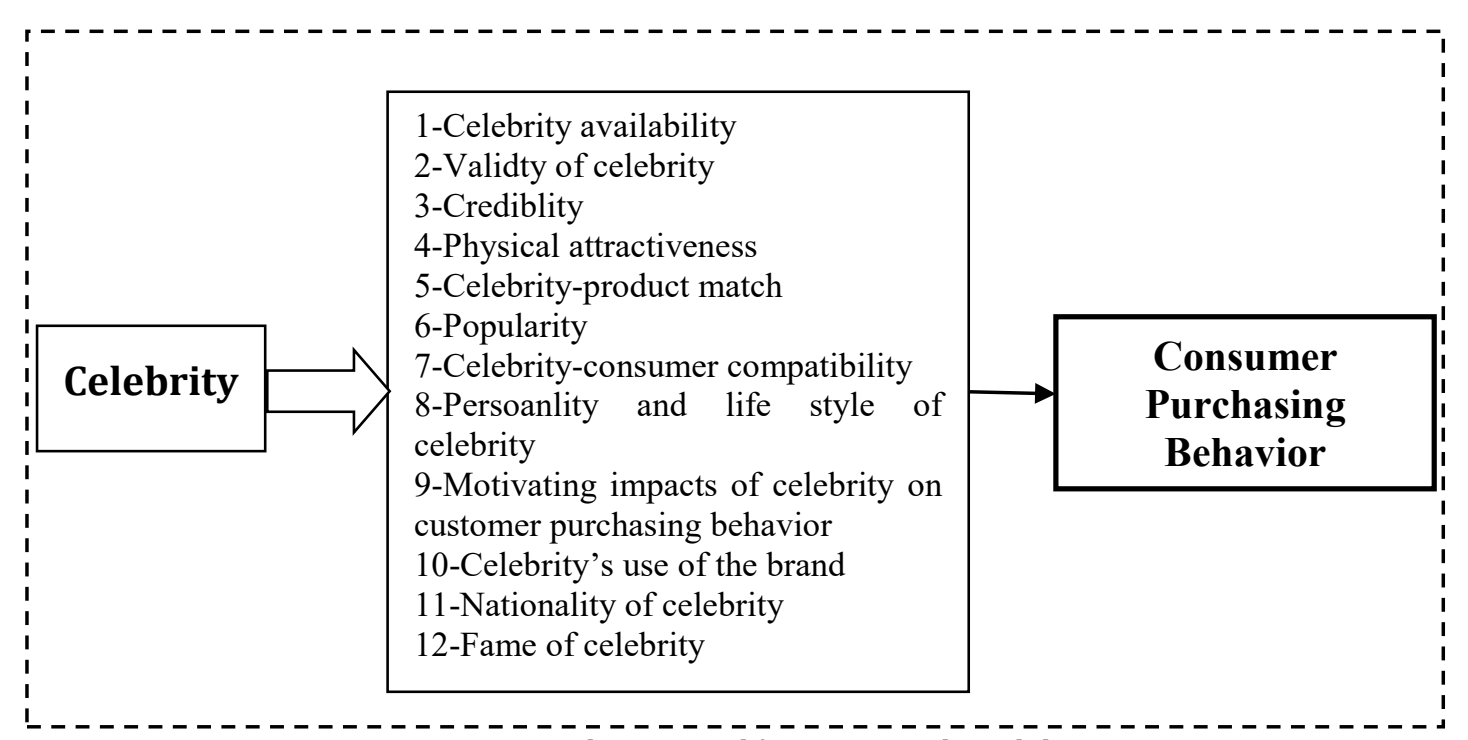

Figure 1. The research's conceptual model

\section{METHODOLOGY}

The purpose of every research is firstly to solve the problems that currently exist in the workplace (applied research), and the secondly to add something new to the treasury of human knowledge in a particular field of interest. The main goal underlying basic research is to produce more knowledge and understanding of the phenomena that occur, and finally to propose theories based on research results. Thus, according to the above definitions, the current research is essentially applied (Uma, 2002).

In the present research, given the temporal and spatial realm of performing the research, the statistical population includes all residents of Mashhad, which are totally more than 3 million. With regard to the subject and hypotheses, the current research is applied in term of objective, and it is explorative-survey in terms of methodology, and the relevant data was collected by questionnaire and survey methods. The research seeks to examine the effects of celebrity endorsement of sporting goods on customer purchasing, and to compare the effectiveness of the relevant components on demographic indicators.

\section{Sample and sampling}

Statistical sample is a collection of individuals who are elected by using statistical sampling procedures (Vatandoust, 2008). In the current research, given the characteristics of the statistical population, two-stage cluster sampling method was used. In this method, every citizen of Mashhad was considered a sample unit.

Sample size: To determine the required sample size, Jersey Morgan Table was used (Khalatbari, 2007). Based on Morgan Table Formula, the number of the samples in the statistical population with a volume of over one million people, is 384 . Thus, by choosing at least 384 individuals out of the statistical sample, the work will be carried out. However, in order to prevent the loss of the respondents, and also to achieve data required based on the sample estimation, 450 questionnaires were distributed, and then after data collection and the removal of incomplete and flawed questionnaires, 384 questionnaires were returned, and this number was regarded as the final sample.

Data collection tools: given the research objectives, the best way to collect information was use of questionnaire. After numerous studies and interviews with the subjects and experts, standard questionnaires were determined to be used in the research. To collect the required data, in accordance with the literature and research background and according to the supervisor's views and also 
imitation of the standard and credible samples, the researcher in consultation with the supervisor decided to use the self-made questionnaire. The questionnaire consisted of two parts.

A) General questions: In general questions, the main goal is to obtain respondents' general and demographic information. This section contains five questions, and issues such as gender, age, marital status, education level, and employment status are considered.

B) The questionnaire of the impact of celebrity endorsement of sporting goods on customer purchasing behavior: this self-made questionnaire was provided based on documentary studies and includes 42 questions under twelve headings.

\section{Validity}

The validity which is also so called symbolic or formal validity means necessity for a research to be logical, interesting, and physically proportionate. Formal validity addresses the fact that how much test questions have been able to be compatible with the subject under study. A test is formally valid if its items are similar to the subject that have been developed to measure it (Rezaeifar \& Montazer Ataei, 2015). According to the above explanation, in the current research, the opinions of the supervisors and observers of the research were utilized to determine formal validity. Meanwhile, in a preliminary sample, the reliability of the research tool was also examined, and the result was higher than 0.7 .

The reliability (internal validity): In the present research, Cronbach's alpha used as a basis for measuring the reliability in most of research was utilized. The reliability is the repeatability of measurement method or tool. The consistency of the results obtained from test-retest and with the use of gauge is called reliability. If the method does not meet the reliability, the validity of collected data cannot be corroborated (Ahmadi et al., 2011). In the following, the reliability of the research questionnaire was calculated based on Cronbach's alpha coefficient, and the results are presented here.

Table 1

Cronbach's alpha coefficients for the variables in the final sample

\begin{tabular}{c|rr|c}
\hline Row & Items' Headings & $\begin{array}{c}\text { Chronach's } \\
\text { Alpha } \\
\text { Coefficient }\end{array}$ \\
\hline \hline 1 & Celebrity availability & 0.7564 \\
2 & Validity of celebrity & 0.7334 \\
\hline 3 & Credibility & 0.7058 \\
\hline 4 & Physical attraction & 0.7616 \\
\hline 5 & Celebrity-product match & 0.7698 \\
\hline 6 & Celebrity-consumer compatibility & 0.7570 \\
\hline 7 & Personality and life style of celebrity & 0.7298 \\
\hline 8 & Motivating impacts of celebrity on people's purchasing behavior & 0.7326 \\
\hline 9 & Celebrity's using of brand & 0.7076 \\
\hline 10 & rationality of celebrity & 0.7053 \\
\hline 11 & & Fame of celebrity & 0.7628 \\
\hline 12 & & & 0.9040 \\
\hline \hline
\end{tabular}

\section{Statistical Methods}

In the current research, with an aim to analyze the data, descriptive and inferential statistical methods were used. In descriptive statistics, frequency tables, mean, and standard deviation were sued, and in inferential statistics, Kolmogorov-Smirnov test were applied to determine the normality 
of variables. In addition, structural equation modeling tests were used to respond to the research hypotheses. Meanwhile, for the calculation and data processing, software SPSS was used.

\section{FINDINGS}

\section{Descriptive findings}

At any research, descriptive statistics and demographic variables are an important part of the process and play significant roles. Accordingly, the analysis of such data will be useful in the process of research. In this part, the demographic variables were analyzed, and the collected data described in the form of tables and diagrams.

Table 2

Frequency distribution of the respondent's sex in the study sample

\begin{tabular}{c|c|c}
\hline Sex & Frequency & Percent \\
\hline Male & 134 & 34.9 \\
\hline Female & 241 & 62.8 \\
\hline No response & 9 & 2.3 \\
\hline Total & $\mathbf{3 8 4}$ & $\mathbf{1 0 0}$ \\
\hline
\end{tabular}

Table 3

Frequency distribution of the respondent's age in the study sample

\begin{tabular}{c|c|c}
\hline Age & Frequency & Percent \\
\hline Less than 20 years old & 202 & 52.6 \\
\hline $21-25$ & 45 & 11.7 \\
\hline $26-30$ & 61 & 15.9 \\
\hline $31-35$ & 33 & 8.6 \\
\hline Over 36 & 37 & 9.6 \\
\hline No response & 6 & 1.6 \\
\hline Total & $\mathbf{3 8 4}$ & $\mathbf{1 0 0}$ \\
\hline
\end{tabular}

Table 4

Frequency distribution of the respondent's marriage status in the study sample

\begin{tabular}{c|c|c}
\hline Marriage Status & Frequency & Percent \\
\hline Single & 255 & 66.4 \\
\hline Married & 90 & 23.4 \\
\hline No Response & 39 & 10.2 \\
\hline Total & $\mathbf{3 8 4}$ & $\mathbf{1 0 0}$ \\
\hline
\end{tabular}

Table 5

Frequency distribution of the respondent's education level in the study sample

\begin{tabular}{c|c|c}
\hline Educational Degree & Frequency & Percent \\
\hline \hline Under Diploma & 146 & 38 \\
Diploma & 88 & 22.9 \\
\hline Associate of Art & 26 & 6.8 \\
BA & 87 & 22.7 \\
\hline MA \& Over & 31 & 8.1 \\
\hline No Response & 6 & 1.6 \\
\hline Total & $\mathbf{3 8 4}$ & 100 \\
\hline
\end{tabular}


Table 6

Frequency distribution of the respondent's career status in the study sample

\begin{tabular}{c|c|c}
\hline Occupation & Frequency & Percent \\
\hline \hline Student & 195 & 50.7 \\
College Student & 32 & 8.3 \\
\hline State Employee & 24 & 6.3 \\
\hline Private Jobs & 101 & 26.3 \\
\hline Others & 42 & 6.3 \\
\hline No Response & 8 & 2.1 \\
\hline Total & $\mathbf{3 8 4}$ & 100 \\
\hline
\end{tabular}

\section{The inferential analysis of the findings (research hypothesis test)}

In order to use an appropriate statistical method, first the relevant possible assumptions for the research were studied. As the research variables were of a distanced type, Kolmogorov-Smirnov test was used to test the abnormal distribution of the data. After ensuring the distribution of data, appropriate tests were used. The significance level for statistical comparisons was considered in the level $(\mathrm{p}<0.05)$. It should be noted that the data collected lacked outliers and indifferent data.

\section{Hypothesis testing of normality of variables}

To determine the normality of variables, the significance level must be examined. If the significance level is less than 0.05 , the variable is abnormal, otherwise it is normal. The results are shown in Table 7.

Table 7

Test of Assumption of Variables' Normality

\begin{tabular}{|c|c|c|c|c|c|c|}
\hline \multirow{2}{*}{ Row } & \multirow{2}{*}{ Research Variables } & \multicolumn{2}{|c|}{$\begin{array}{l}\text { Descriptive } \\
\text { Findings } \\
\end{array}$} & \multicolumn{2}{|c|}{ K-s Test } & \multirow{2}{*}{ Result } \\
\hline & & Mean & $\begin{array}{l}\text { Standard } \\
\text { Deviation }\end{array}$ & $\begin{array}{c}\text { K-S } \\
\text { Statistics }\end{array}$ & $\begin{array}{c}\text { Significance } \\
\text { Level }\end{array}$ & \\
\hline 1 & Celebrity availability & 3.29 & 0.72 & 1.808 & 0.003 & Non-normal \\
\hline 2 & Validity of celebrity & 2.75 & 0.88 & 1.505 & 01022 & Non-normal \\
\hline 3 & Credibility & 3.26 & 0.82 & 2.061 & 0.001 & Non-normal \\
\hline 4 & Physical attraction & 3.02 & 1.01 & 2.175 & 0.0001 & Non-normal \\
\hline 5 & Celebrity-product match & 3.14 & 0.92 & 3.143 & 0.0001 & Non-normal \\
\hline 6 & Popularity & 2.72 & 0.87 & 1.946 & 0.001 & Non-normal \\
\hline 7 & Celebrity-consumer compatibility & 2.87 & 0.82 & 1.486 & 0.29 & Normal \\
\hline 8 & $\begin{array}{r}\text { Personality and life style of } \\
\text { celebrity }\end{array}$ & 2.9 & 0.92 & 0.964 & 0.001 & Non-normal \\
\hline 9 & $\begin{array}{l}\text { Motivating impacts of celebrity on } \\
\text { customer purchasing behavior }\end{array}$ & 3.29 & 0.93 & 2.029 & 0.001 & Non-normal \\
\hline 10 & Celebrity's using of brand & 3.29 & 0.89 & 1.955 & 0.001 & Non-normal \\
\hline 11 & Nationality of celebrity & 2.87 & 0.82 & 2.155 & 0.0001 & Non-normal \\
\hline 12 & Fame of celebrity & 3.18 & 880. & 2.155 & 0.0001 & Non-normal \\
\hline- & Total & 3.06 & 0.61 & 1.18 & 0.124 & Normal \\
\hline
\end{tabular}

\section{Exploratory and confirmatory factor analysis}

In the present research, to explore the latent variables and to confirm the measurement model, confirmatory factor analysis was used. In addition, one of the basic applications of such type of analysis is to assess the validity of constituent parts of variables. Therefore, in this study, this technique was used to assess the factor validity. In the research, as the used scales and relevant items were translated into Farsi, the application of exploratory factor analysis seems necessary. Therefore, in this part, using an exploratory factor analysis, the validity of the variables components, and then 
using confirmatory factor analysis, the verification of the results from the factor analysis were determined. Factor analysis can be calculated by the software SPSS and LISREL.

In the current study, exploratory factor analysis obtained from SPSS software was provided by the software LISREL. Furthermore, confirmatory factor analysis obtained from SPSS was used. Factor loading indicates explanation of that variable with related question (Mozaheb et al., 2015). It should be noted that in order to reduce the number of the variables and consider them as a latent variable, the factor loading obtained must be greater than 0.5 (Ghanbari et al., 2015).

Exploratory factor analysis of the research variables: As expected, Kaiser-Meyer-Olkin Measure of Sampling Adequacy (KMO) is equal to 0.904, and the significance number of Bartlett's Test of Sphericity Sig in the exploratory factor analysis by SPSS is 6683.394 and 0.0001 , respectively, indicating the fact that the sample size for factor analysis is appropriate. It should be noted that the twelve factors account for about $66 \%$ of the variance related to consumer purchasing behavior.

Confirmatory factor analysis of the research variables: the results from confirmatory factor analysis show that the obtained factor loadings were greater than 3.0, and 12 questions related to this variable are classified under a distinct factor. Thus, the data of this latent variable are calculated from the average of the questions. Figures 1 and 2 show the results of confirmatory factor analysis to examine the impact of celebrity endorsement of sporting goods on customer purchasing behavior in standard estimation mode and t coefficients.

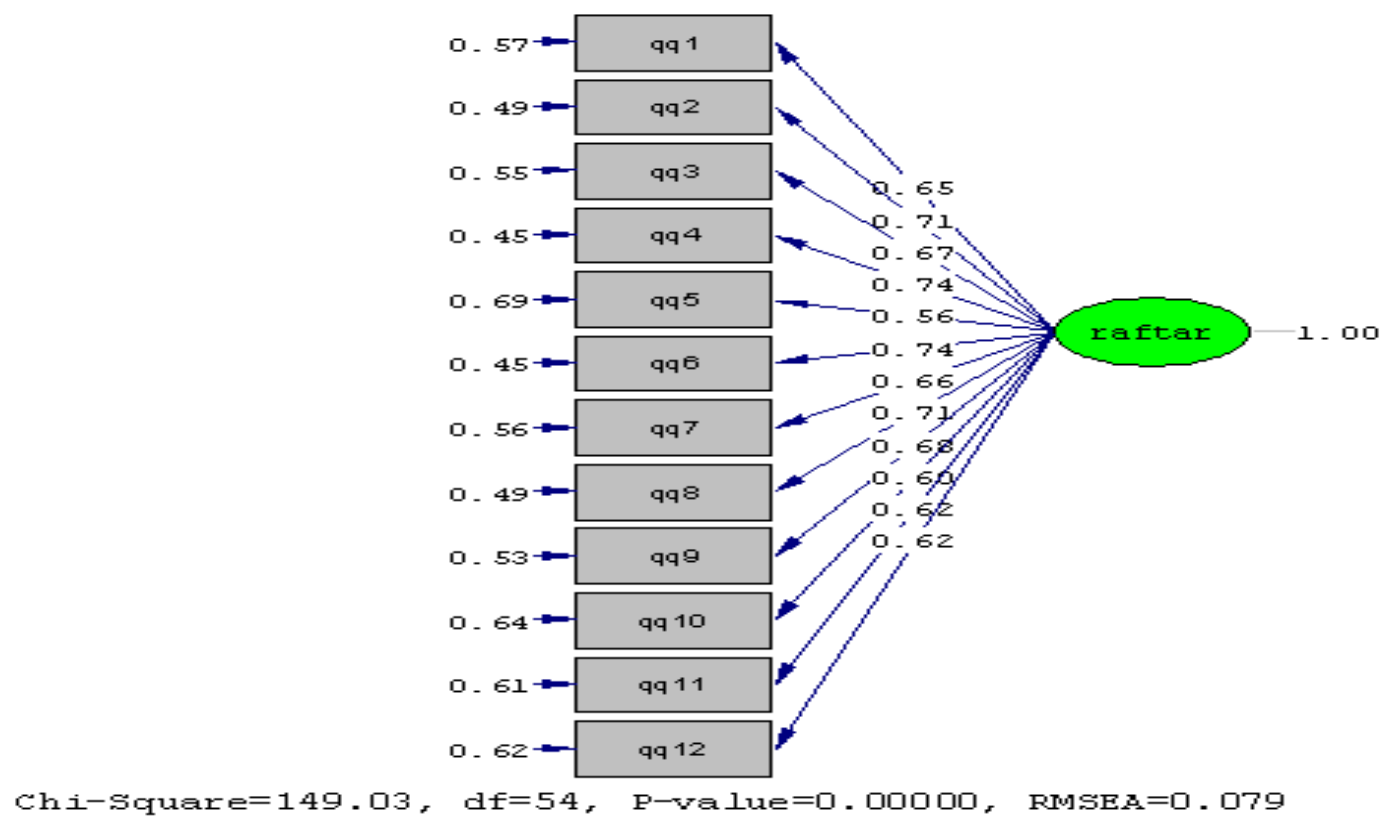

Figure 1. The confirmatory factor analysis using the standard coefficients, the variable of the factors influencing the celebrity endorsement of sporting goods on customer purchasing behavior 


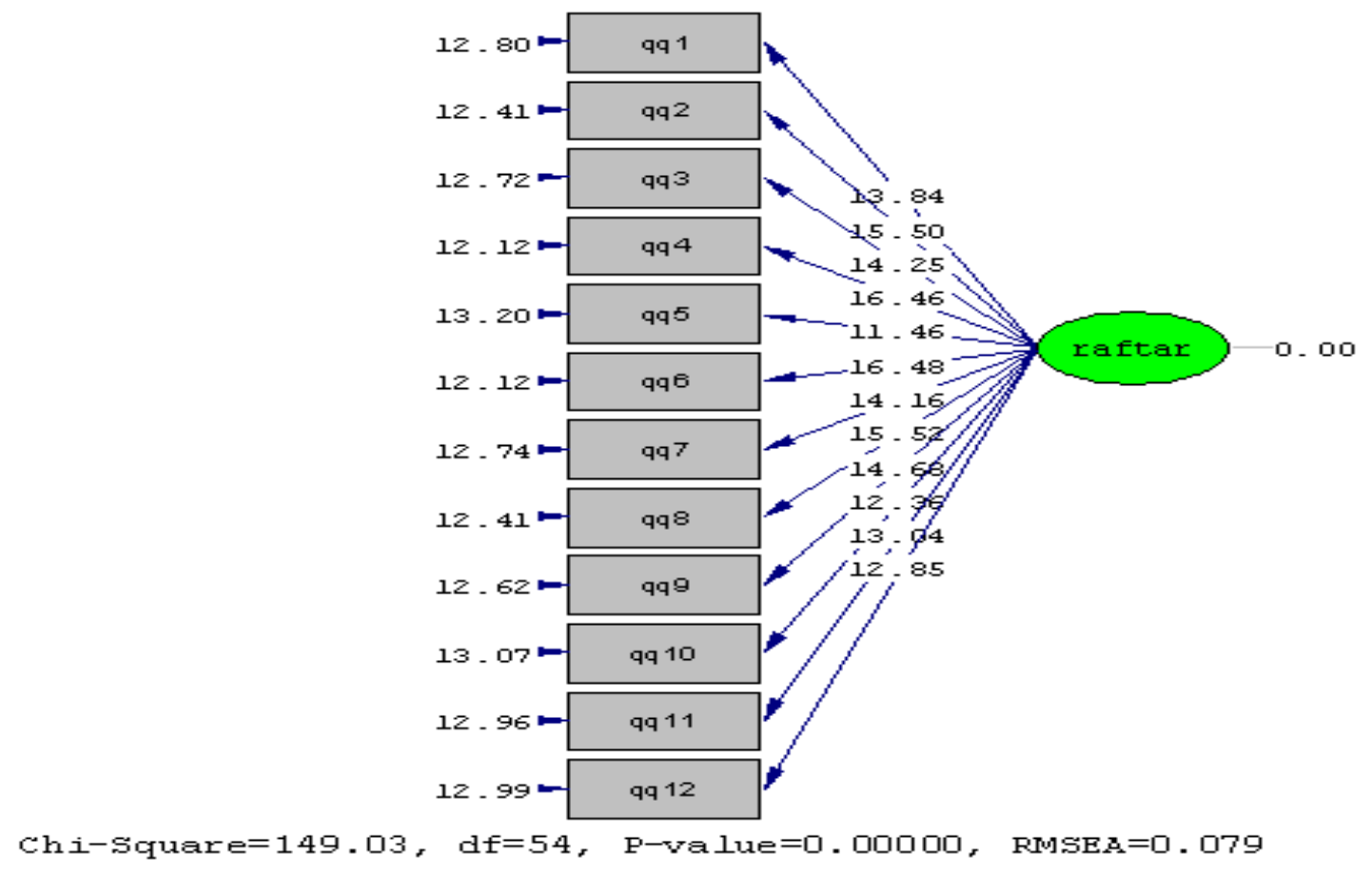

Figure 2. The confirmatory factor analysis using t coefficients, the variable of the factors influencing the celebrity endorsement of sporting goods on customer purchasing behavior

\section{RESEARCH HYPOTHESES TESTING}

\section{The celebrity availability in sporting goods advertising can influence consumer purchasing behavior}

Given the variable "celebrity availability in sporting goods advertising can influence consumer purchasing behavior" which was tested by the items 1-7 in the questionnaire and has a normal distribution, the single variable non-parametric sign test was utilized to do hypothesis testing. The following hypotheses must be tested:

$\mathbf{H}_{\mathbf{0}}$ The celebrity availability in sporting goods advertising cannot influence consumer purchasing behavior.

$\mathbf{H}_{\mathbf{1}}$ The celebrity availability in sporting goods advertising can influence consumer purchasing behavior.

\section{Table 8}

The results from non-parametric sign test of the positive impact of the celebrity availability in sporting goods advertising on consumer purchasing behavior.

\begin{tabular}{ccccccc}
\hline Mean & $\begin{array}{c}\text { Standard } \\
\text { Deviation }\end{array}$ & Median & $\begin{array}{c}\text { Number } \\
\text { less than } \\
\text { Median }\end{array}$ & $\begin{array}{c}\text { Mean } \\
\text { Equivalent } \\
\text { Number }\end{array}$ & $\begin{array}{c}\text { Number } \\
\text { Greater than } \\
\text { Median }\end{array}$ & $\begin{array}{c}\text { Significance } \\
\text { Level }\end{array}$ \\
\hline 3.29 & 0.72 & 3.429 & 108 & 30 & 246 & 0.001 \\
\hline
\end{tabular}

As indicated in the table 8 , the mean of the variable "positive impact of the celebrity availability in sporting goods advertising on consumer purchasing behavior" is 3.29 with the standard deviation of 0.72 , and the median 3.429. In addition, the significance level of the sign test is 0.0001 , so at the level $\alpha=0.05$, the zero hypothesis is rejected and opposite hypothesis is confirmed, i.e. the celebrity availability in sporting goods advertising can influence consumer purchasing behavior. 


\section{The validity of celebrity in adoption of sporting goods advertising can influence consumer purchasing attitude.}

Given the second variable of the research, that was tested by the items 8-11 in the questionnaire and has an abnormal distribution, the single variable non-parametric sign test was utilized to do hypothesis testing. The following hypotheses must be tested:

$\mathbf{H}_{\mathbf{0}}$ The validity of celebrity in adoption of sporting goods advertising cannot influence consumer purchasing attitude.

$\mathbf{H}_{\mathbf{1}}$ The presence of celebrity in sporting goods advertising can influence consumer purchasing behavior.

Table 9

The results from non-parametric sign test on the positive impact of the validity of celebrity in sporting goods advertising on consumer purchasing behavior.

\begin{tabular}{ccccccc}
\hline Mean & $\begin{array}{c}\text { Standard } \\
\text { Deviation }\end{array}$ & Median & $\begin{array}{c}\text { Number } \\
\text { less than } \\
\text { Median }\end{array}$ & $\begin{array}{c}\text { Mean } \\
\text { Equivalent } \\
\text { Number }\end{array}$ & $\begin{array}{c}\text { Number } \\
\text { Greater than } \\
\text { Median }\end{array}$ & $\begin{array}{c}\text { Significanc } \\
\text { e Level }\end{array}$ \\
\hline 2.75 & 0.88 & 2.75 & 204 & 49 & 131 & 0.99 \\
\hline
\end{tabular}

As indicated in the table 9, the mean of the variable "positive impact of the validity of celebrity in sporting goods advertising on consumer purchasing behavior" is 2.75 with the standard deviation of 0.88 , and the median 52.7. In addition, the significance level of the sign test is 0.99 , so at the level $\alpha=$ 0.05 , the zero hypothesis is not rejected and confirmed, i.e. the validity of celebrity in sporting goods advertising cannot influence consumer purchasing behavior.

\section{The credibility of celebrity in adoption of sporting goods advertising can influence consumer purchasing attitude}

Given the third variable of the research, that was tested by the items $12-15$ in the questionnaire and has an abnormal distribution, the single variable non-parametric sign test was utilized to do hypothesis testing. The following hypotheses must be tested:

$\mathbf{H}_{\mathbf{0}}$ The credibility of celebrity in adoption of sporting goods advertising cannot influence consumer purchasing attitude.

$\mathbf{H}_{\mathbf{1}}$ The credibility of celebrity in sporting goods advertising can influence consumer purchasing behavior.

\section{Table 10}

The results from non-parametric sign test on the positive impact of the credibility of celebrity in sporting goods advertising on consumer purchasing behavior.

\begin{tabular}{ccccccc}
\hline Mean & $\begin{array}{c}\text { Standard } \\
\text { Deviation }\end{array}$ & Median & $\begin{array}{c}\text { Number } \\
\text { less than } \\
\text { Median }\end{array}$ & $\begin{array}{c}\text { Mean } \\
\text { Equivalent } \\
\text { Number }\end{array}$ & $\begin{array}{c}\text { Number Greater } \\
\text { than Median }\end{array}$ & $\begin{array}{c}\text { Significan } \\
\text { ce Level }\end{array}$ \\
\hline 3.26 & 0.82 & 3.269 & 106 & 48 & 230 & 0.0001 \\
\hline
\end{tabular}

As indicated in the table 10, the mean of the variable "positive impact of the credibility of celebrity in sporting goods advertising on consumer purchasing behavior" is 3.26 with the standard deviation of 0.82 , and the median 3.269. In addition, the significance level of the sign test is 0.0001 , so at the level $\alpha=0.05$, the zero hypothesis is rejected and the opposite hypothesis confirmed, i.e. the credibility of celebrity in sporting goods advertising can influence consumer purchasing behavior. 


\section{The physical attractiveness of celebrity in adoption of sporting goods advertising can influence consumer purchasing attitude}

Given the fourth variable of the research, that was tested by the items $16-17$ in the questionnaire and has an abnormal distribution, the single variable non-parametric sign test was utilized to do hypothesis testing. The following hypotheses must be tested:

$\mathbf{H}_{\mathbf{0}}$ The attractiveness of celebrity in adoption of sporting goods advertising cannot influence consumer purchasing attitude.

$\mathbf{H}_{\mathbf{1}}$ The attractiveness of celebrity in sporting goods advertising can influence consumer purchasing behavior.

\section{Table 11}

The results from non-parametric sign test on the positive impact of the physical attractiveness of celebrity in sporting goods advertising on consumer purchasing behavior.

\begin{tabular}{ccccccc}
\hline Mean & $\begin{array}{c}\text { Standard } \\
\text { Deviation }\end{array}$ & Median & $\begin{array}{c}\text { Number } \\
\text { less than } \\
\text { Median }\end{array}$ & $\begin{array}{c}\text { Mean } \\
\text { Equivalent } \\
\text { Number }\end{array}$ & $\begin{array}{c}\text { Number } \\
\text { Greater than } \\
\text { Median }\end{array}$ & $\begin{array}{c}\text { Significance } \\
\text { Level }\end{array}$ \\
\hline 3.02 & 1.01 & 3 & 146 & 75 & 163 & 0.181 \\
\hline
\end{tabular}

As indicated in the table 11, the mean of the variable "positive impact of the attractiveness of celebrity in sporting goods advertising on consumer purchasing behavior" is 3.02 with the standard deviation of 0.01 , and the median 3. In addition, the significance level of the sign test is 0.181 , so at the level $\alpha=0.05$, the zero hypothesis is not rejected and confirmed, i.e. the attractiveness of celebrity in sporting goods advertising cannot influence consumer purchasing behavior.

\section{Celebrity-product match in the adoption of sporting goods advertising can influence consumer purchasing attitude.}

Given the fifth variable of the research, that was tested by the items 19-19 in the questionnaire and has an abnormal distribution, the single variable non-parametric sign test was utilized to do hypothesis testing. The following hypotheses must be tested:

$\mathbf{H}_{\mathbf{0}}$ Celebrity-product match in the adoption of sporting goods advertising can influence consumer purchasing attitude.

$\mathbf{H}_{\mathbf{1}}$ Celebrity-product match in the adoption of sporting goods advertising can influence consumer purchasing attitude.

\section{Table 12}

The results from non-parametric sign test on the positive impact of celebrity-product match in sporting goods advertising on consumer purchasing behavior

\begin{tabular}{ccccccc}
\hline Mean & $\begin{array}{c}\text { Standard } \\
\text { Deviation }\end{array}$ & Median & $\begin{array}{c}\text { Number } \\
\text { less than } \\
\text { Median }\end{array}$ & $\begin{array}{c}\text { Mean } \\
\text { Equivalent } \\
\text { Number }\end{array}$ & $\begin{array}{c}\text { Number } \\
\text { Greater than } \\
\text { Median }\end{array}$ & $\begin{array}{c}\text { Significanc } \\
\text { e Level }\end{array}$ \\
\hline 3.14 & 0.92 & 3 & 106 & 102 & 176 & 0.0001 \\
\hline
\end{tabular}

As indicated in the table 12, the mean of the variable "positive impact of celebrity-product match in adoption of sporting goods advertising on consumer purchasing behavior" is 3.14 with the standard deviation of 0.92 , and the median 3 . In addition, the significance level of the sign test is 0.0001 , so at the level $\alpha=0.05$, the zero hypothesis is rejected and the opposite hypothesis is confirmed, i.e. celebrity-product match in sporting goods advertising can influence consumer purchasing behavior. 


\section{The popularity of celebrity in the adoption of sporting goods advertising can influence consumer purchasing attitude.}

Given the fifth variable of the research, that was tested by the items 20-22 in the questionnaire and has an abnormal distribution, the single variable non-parametric sign test was utilized to do hypothesis testing. The following hypotheses must be tested:

$\mathbf{H}_{\mathbf{0}}$ The popularity of celebrity in the adoption of sporting goods advertising cannot influence consumer purchasing attitude.

$\mathbf{H}_{\mathbf{1}}$ The popularity of celebrity in the adoption of sporting goods advertising can influence consumer purchasing attitude.

Table 13

The results from non-parametric sign test on the positive impact of the popularity of celebrity in sporting goods advertising on consumer purchasing behavior.

\begin{tabular}{ccccccc}
\hline Mean & $\begin{array}{c}\text { Standard } \\
\text { Deviation }\end{array}$ & Median & $\begin{array}{c}\text { Number } \\
\text { less than } \\
\text { Median }\end{array}$ & $\begin{array}{c}\text { Mean } \\
\text { Equivalent } \\
\text { Number }\end{array}$ & $\begin{array}{c}\text { Number } \\
\text { Greater than } \\
\text { Median }\end{array}$ & $\begin{array}{c}\text { Significanc } \\
\text { e Level }\end{array}$ \\
\hline 2.72 & 0.87 & 2.67 & 201 & 71 & 112 & 0.99 \\
\hline
\end{tabular}

As indicated in the table 13, the mean of the variable "positive impact of the popularity of celebrity in adoption sporting goods advertising on consumer purchasing behavior" is 2.72 with the standard deviation of 0.87 , and the median 2.67. In addition, the significance level of the sign test is 0.99 , so at the level $\alpha=0.05$, the zero hypothesis is not rejected and confirmed, i.e. the popularity of celebrity in adoption sporting goods advertising cannot influence consumer purchasing behavior.

\section{The celebrity-consumer compatibility in adoption of sporting goods advertising can influence consumer purchasing attitude}

Given the seventh variable of the research, that was tested by the items 23-27 in the questionnaire and has a normal distribution, the single variable non-parametric sign test was utilized to do hypothesis testing. The following hypotheses must be tested:

$\mathbf{H}_{\mathbf{0}}$ The celebrity-consumer compatibility in adoption of sporting goods advertising cannot influence consumer purchasing attitude.

$\mathbf{H}_{1}$ The celebrity-consumer compatibility in adoption of sporting goods advertising can influence consumer purchasing behavior.

Table 14

The results obtained from single sample t-test of the positive impact of the celebrity-consumer compatibility in the adoption of sporting goods advertising on consumer purchasing attitude.

\begin{tabular}{ccccccc}
\hline Mean & $\begin{array}{c}\text { Standard } \\
\text { Deviation }\end{array}$ & Median & $\begin{array}{c}\text { Number } \\
\text { less than } \\
\text { Median }\end{array}$ & $\begin{array}{c}\text { Mean } \\
\text { Equivalent } \\
\text { Number }\end{array}$ & $\begin{array}{c}\text { Number } \\
\text { Greater than } \\
\text { Median }\end{array}$ & $\begin{array}{c}\text { Significance } \\
\text { Level }\end{array}$ \\
\hline 2.87 & 0.82 & 2.875 & 197 & 30 & 157 & 0.98 \\
\hline
\end{tabular}

As indicated in the table 14 , the mean of the variable "positive impact of the celebrityconsumer compatibility in adoption of sporting goods advertising on consumer purchasing behavior" is 2.87 with the standard deviation of 0.82 , and the median 2.875 . In addition, statistic value $t$ is -2.98 and the significance level of the sign test is 0.098 , so at the level $\alpha=0.05$, the zero hypothesis is not rejected and is confirmed, i.e. the celebrity-consumer compatibility in adoption of sporting goods advertising cannot influence consumer purchasing behavior. 


\section{The personality and life style of celebrity in the adoption of sporting goods advertising can influence consumer purchasing attitude}

Given the fifth variable of the research, that was tested by the items 28-30 in the questionnaire and has an abnormal distribution, the single variable non-parametric sign test was utilized to do hypothesis testing. The following hypotheses must be tested:

$\mathbf{H}_{\mathbf{0}}$ The personality and life style of celebrity in the adoption of sporting goods advertising cannot influence consumer purchasing attitude.

$\mathbf{H}_{\mathbf{1}}$ The personality and life style of celebrity in the adoption of sporting goods advertising can influence consumer purchasing attitude.

Table 15

The results obtained from non-parametric sign test on the positive impact of personality and life style of celebrity in the adoption of sporting goods advertising on consumer purchasing attitude.

\begin{tabular}{ccccccc}
\hline Mean & $\begin{array}{c}\text { Standard } \\
\text { Deviation }\end{array}$ & Median & $\begin{array}{c}\text { Number } \\
\text { less than } \\
\text { Median }\end{array}$ & $\begin{array}{c}\text { Mean } \\
\text { Equivalent } \\
\text { Number }\end{array}$ & $\begin{array}{c}\text { Number } \\
\text { Greater than } \\
\text { Median }\end{array}$ & $\begin{array}{c}\text { Significance } \\
\text { Level }\end{array}$ \\
\hline 2.9 & 0.92 & 3 & 169 & 62 & 153 & 0.83 \\
\hline
\end{tabular}

As indicated in the table 15, the mean of the variable "positive impact of the personality and life style of celebrity in adoption sporting goods advertising on consumer purchasing behavior" is 2.9 with the standard deviation of 0.92 , and the median 3 . In addition, the significance level of the sign test is 0.83 , so at the level $\alpha=0.05$, the zero hypothesis is not rejected and confirmed, i.e. the personality and life style of celebrity in adoption of sporting goods advertising cannot influence consumer purchasing behavior.

\section{The stimulating power of celebrity in adoption of sporting goods advertising can influence consumer purchasing attitude}

Given the ninth variable of the research, that was tested by the items $31-33$ in the questionnaire and has an abnormal distribution, the single variable non-parametric sign test was utilized to do hypothesis testing. The following hypotheses must be tested:

$\mathbf{H}_{\mathbf{0}}$ The stimulating power of celebrity in adoption of sporting goods advertising cannot influence consumer purchasing attitude.

$\mathbf{H}_{\mathbf{1}}$ The stimulating power of celebrity in sporting goods advertising can influence consumer purchasing behavior.

Table 16

The results obtained from non-parametric sign test on the positive impact of stimulating power of celebrity in the adoption of sporting goods advertising on consumer purchasing attitude.

\begin{tabular}{ccccccc}
\hline Mean & $\begin{array}{c}\text { Standard } \\
\text { Deviation }\end{array}$ & Median & $\begin{array}{c}\text { Number } \\
\text { less than } \\
\text { Median }\end{array}$ & $\begin{array}{c}\text { Mean } \\
\text { Equivalent } \\
\text { Number }\end{array}$ & $\begin{array}{c}\text { Number } \\
\text { Greater than } \\
\text { Median }\end{array}$ & $\begin{array}{c}\text { Significance } \\
\text { Level }\end{array}$ \\
\hline 3.29 & 0.93 & 3.33 & 109 & 54 & 221 & 0.0001 \\
\hline
\end{tabular}

As indicated in the table 16, the mean of the variable "positive impact of the stimulating power of celebrity in adoption of sporting goods advertising on consumer purchasing behavior" is 3.29 with the standard deviation of 0.93 , and the median 3.33. In addition, the significance level of the sign test is 0.0001 , so at the level $\alpha=0.05$, the zero hypothesis is rejected and the opposite hypothesis is 
confirmed, i.e. the stimulating power of celebrity in adoption of sporting goods advertising can influence consumer purchasing behavior.

\section{The celebrity's use of brand can influence the adoption of sporting goods from consumer purchasing attitude}

Given the tenth variable of the research, that was tested by the items 3-36 in the questionnaire and has an abnormal distribution, the single variable non-parametric sign test was utilized to do hypothesis testing. The following hypotheses must be tested:

$\mathbf{H}_{\mathbf{0}}$ The celebrity's use of brand cannot influence the adoption of sporting goods from consumer purchasing attitude

$\mathbf{H}_{\mathbf{1}}$ The celebrity's use of brand can influence the adoption of sporting goods from consumer purchasing attitude.

\section{Table 17}

The results obtained from non-parametric sign test on the positive impact of the celebrity's use of brand on the adoption of sporting goods from consumer purchasing attitude.

\begin{tabular}{ccccccc}
\hline Mean & $\begin{array}{c}\text { Standard } \\
\text { Deviation }\end{array}$ & Median & $\begin{array}{c}\text { Number } \\
\text { less than } \\
\text { Median }\end{array}$ & $\begin{array}{c}\text { Mean } \\
\text { Equivalent } \\
\text { Number }\end{array}$ & $\begin{array}{c}\text { Number } \\
\text { Greater than } \\
\text { Median }\end{array}$ & $\begin{array}{c}\text { Significance } \\
\text { Level }\end{array}$ \\
\hline 3.29 & 0.98 & 3.3 & 104 & 57 & 223 & 0.0001 \\
\hline
\end{tabular}

As indicated in the table 17, the mean of the variable "positive impact of celebrity's use of brand on the adoption of sporting goods from consumer purchasing attitude" is 3.29 with the standard deviation of 0.89 , and the median 3.3. In addition, the significance level of the sign test is 0.0001 , so at the level $\alpha=0.05$, the zero hypothesis is rejected and the opposite hypothesis is confirmed, i.e. the applicability of celebrity to trade mark can have impact on the adoption of sporting goods from consumer purchasing attitude.

\section{The nationality of celebrity in adoption of sporting goods advertising can influence consumer purchasing attitude}

Given the eleventh variable of the research, that was tested by the items 37-39 in the questionnaire and has an abnormal distribution, the single variable non-parametric sign test was utilized to do hypothesis testing. The following hypotheses must be tested:

$\mathbf{H}_{\mathbf{0}}$ The nationality of celebrity in adoption of sporting goods advertising cannot influence consumer purchasing attitude.

$\mathbf{H}_{\mathbf{1}}$ The nationality of celebrity in sporting goods advertising can influence consumer purchasing behavior.

\section{Table 18}

The results obtained from non-parametric sign test on the positive impact of nationality of celebrity in the adoption of sporting goods advertising on consumer purchasing attitude.

\begin{tabular}{ccccccc} 
Mean & $\begin{array}{c}\text { Standard } \\
\text { Deviation }\end{array}$ & Median & $\begin{array}{c}\text { Number } \\
\text { less than } \\
\text { Median }\end{array}$ & $\begin{array}{c}\text { Mean } \\
\text { Equivalent } \\
\text { Number }\end{array}$ & $\begin{array}{c}\text { Number Greater } \\
\text { than Median }\end{array}$ & $\begin{array}{c}\text { Significance } \\
\text { Level }\end{array}$ \\
\hline 2.87 & 0.82 & 3 & 176 & 67 & 141 & 0.97
\end{tabular}

As indicated in the table 18, the mean of the variable "positive impact of the nationality of celebrity in adoption of sporting goods advertising on consumer purchasing behavior" is 2.87 with the standard deviation of 0.82 , and the median 3. In addition, the significance level of the sign test is 0.97 , so at the level $\alpha=0.05$, the null hypothesis is not rejected and the opposite hypothesis is confirmed, i.e. 
the stimulating power of celebrity in adoption of sporting goods advertising cannot influence consumer purchasing behavior.

\section{The fame of celebrity in adoption of sporting goods advertising can influence consumer purchasing attitude}

Given the ninth variable of the research, that was tested by the items 40-42 in the questionnaire and has an abnormal distribution, the single variable non-parametric sign test was utilized to do hypothesis testing. The following hypotheses must be tested:

$\mathbf{H}_{\mathbf{0}}$ The fame of celebrity in adoption of sporting goods advertising cannot influence consumer purchasing attitude.

$\mathbf{H}_{\mathbf{1}}$ The fame of celebrity in sporting goods advertising can influence consumer purchasing behavior.

\section{Table 19}

The results obtained from non-parametric sign test on the positive impact of fame of celebrity in the adoption of sporting goods advertising on consumer purchasing attitude.

\begin{tabular}{ccccccc}
\hline Mean & $\begin{array}{c}\text { Standard } \\
\text { Deviation }\end{array}$ & Median & $\begin{array}{c}\text { Number } \\
\text { less than } \\
\text { Median }\end{array}$ & $\begin{array}{c}\text { Mean } \\
\text { Equivalent } \\
\text { Number }\end{array}$ & $\begin{array}{c}\text { Number } \\
\text { Greater than } \\
\text { Median }\end{array}$ & $\begin{array}{c}\text { Significance } \\
\text { Level }\end{array}$ \\
\hline 3.18 & 0.88 & 3.26 & 117 & 72 & 195 & 0.0001 \\
\hline
\end{tabular}

As indicated in the table 19, the mean of the variable "positive impact of the fame of celebrity in adoption sporting goods advertising on consumer purchasing behavior" is 3.18 with the standard deviation of 0.88 , and the median 3.26. In addition, the significance level of the sign test is 0.0001 , so at the level $\alpha=0.05$, the zero hypothesis is rejected and the opposite hypothesis is confirmed, i.e. the fame of celebrity in adoption of sporting goods advertising can influence consumer purchasing behavior.

\section{Comparison and ranking}

Question 1: now the question is this: what are the most effective and significant factors (among the ones presented in the current research) that can influence the adoption of sporting goods from consumer's perspective. Therefore, using Friedman test, the factors influencing consumer purchasing behavior are prioritized.

Null hypothesis: there cannot establish any priority among the factors affecting the adoption of sporting goods advertisement from a consumer perspective.

Hypothesis one: there can establish a priority among the factors affecting the adoption of sporting goods advertisement from a consumer perspective.

Table 20:

Freidman test on priority of the factors affecting the adoption of sporting goods advertisement from a consumer perspective.

\begin{tabular}{c|c|c}
\hline Row & Statistics & Value \\
\hline \hline 1 & Freidman K2 & 411.304 \\
\hline 2 & Degree of Freedom & 11 \\
\hline 3 & Significance Level & 0.0001 \\
\hline
\end{tabular}

As seen in Table 20, as significance level of Friedman test is 0.0001 , the null hypothesis is rejected, and the hypothesis one is accepted, i.e. there is the priority. 
Table 21

Mean of ranking for the priority of the factors affecting the adoption of sporting goods advertisement from a consumer perspective.

\begin{tabular}{r|c|c}
\hline \multicolumn{1}{c|}{ Factors } & Mean Rank & Priority \\
\hline \hline 1- Celebrity availability & 7.78 & $1^{\text {st }}$ \\
\hline 2-Validty of celebrity & 5.07 & $11^{\text {th }}$ \\
\hline 3-Crediblity & 7.67 & $3^{\text {rd }}$ \\
\hline 4-Physical attraction & 6.38 & $7^{\text {th }}$ \\
\hline 5-Celebrity-product match & 6.96 & $6^{\text {th }}$ \\
\hline 6-Popularity & 4.74 & $12^{\text {th }}$ \\
\hline 7- Celebrity-consumer compatibility & 5.56 & $10^{\text {th }}$ \\
\hline 8-Persoanlity and life style of celebrity & 5.86 & $8^{\text {th }}$ \\
\hline 9-Motivating impacts of celebrity on customer & 7.67 & $2^{\text {nd }}$ \\
\hline purchasing behavior & & $4^{\text {th }}$ \\
\hline 10-Celebrity's use of brand & 7.46 & $9^{\text {th }}$ \\
\hline 11-Nationality of celebrity & 5.65 & $5^{\text {th }}$ \\
\hline
\end{tabular}

As shown in Table 21, the celebrity availability has the highest impact and importance, and then motivation, credibility, celebrity's use of brand, fame, and celebrity-product match, respectively. The lowest factor was popularity and then validity.

Question 2: what are the most effective and significant factors (among the different age groups of the respondents in the current research) that can influence the adoption of sporting goods from consumer's perspective. Therefore, using Friedman test, the factors influencing consumer purchasing behavior are prioritized. Table 22 shows the priority of the factors affecting the adoption of sporting goods advertisement from a consumer perspective at different age groups.

\section{Table 22}

The priority of the factors affecting the adoption of sporting goods advertisement from a consumer perspective at different age groups.

\begin{tabular}{r|c|c|c|c|c|c|c|c}
\hline Row & $\begin{array}{c}\text { Age } \\
\text { Group }\end{array}$ & $\begin{array}{c}\text { Friedman } \\
\text { K2 }\end{array}$ & $\begin{array}{c}\text { Degree } \\
\text { of } \\
\text { Freedom }\end{array}$ & $\begin{array}{c}\text { Significance } \\
\text { Level }\end{array}$ & Priority 1 & Priority 2 & Priority 3 & $\begin{array}{c}\text { Priority } \\
\mathbf{1 2}\end{array}$ \\
\hline \hline & $\begin{array}{c}\text { Less } \\
\text { than 20 } \\
\text { Years }\end{array}$ & 226.259 & 11 & 0.0001 & $\begin{array}{c}\text { Celebrity } \\
\text { Availability }\end{array}$ & $\begin{array}{c}\text { Celebrity's } \\
\text { Use of } \\
\text { Product }\end{array}$ & Motivation & Nationality \\
\hline 2 & $21-25$ & 43.259 & 11 & 0.0001 & $\begin{array}{c}\text { Croduct- } \\
\text { Match }\end{array}$ & Credibility & Fame & Popularity \\
\hline 4 & $26-30$ & 76.982 & 11 & 0.0001 & Motivation & Credibility & $\begin{array}{c}\text { Celebrity } \\
\text { Availability }\end{array}$ & Popularity \\
\hline 5 & Over 35 & 59.472 & 11 & 0.0001 & $\begin{array}{c}\text { Celebrity } \\
\text { Availability }\end{array}$ & Credibility & Motivation & Validity \\
\hline
\end{tabular}

Question 3: what are the most effective and significant factors (among two sexes in the current research) that can influence the adoption of sporting goods from consumer's perspective. Therefore, using Friedman test, the factors influencing consumer purchasing behavior are prioritized. Table 23 shows the priority of the factors affecting the adoption of sporting goods advertisement from a consumer perspective among two sexes. 
Table 23

The priority of the factors affecting the adoption of sporting goods advertisement from a consumer perspective among two sexes.

\begin{tabular}{r|c|c|c|c|c|c|c|c}
\hline Row & Sex & $\begin{array}{c}\text { Friedman } \\
\text { K2 }\end{array}$ & $\begin{array}{c}\text { Degree } \\
\text { of } \\
\text { Freedom }\end{array}$ & $\begin{array}{c}\text { Significance } \\
\text { Level }\end{array}$ & Priority 1 & Priority 2 & Priority 3 & $\begin{array}{c}\text { Priority } \\
\mathbf{1 2}\end{array}$ \\
\hline \hline 1 & Male & 243.316 & 11 & 0.0001 & $\begin{array}{c}\text { Celebrity's } \\
\text { Use of } \\
\text { Brand }\end{array}$ & Motivation & $\begin{array}{c}\text { Celebrity } \\
\text { Availability }\end{array}$ & Popularity \\
\hline 2 & Female & 215.449 & 11 & 0.0001 & $\begin{array}{c}\text { Celebrity } \\
\text { Availability }\end{array}$ & Credibility & Motivation & Popularity \\
\hline
\end{tabular}

Question 4: what are the most effective and significant factors (among different education levels of the respondents in the current research) that can influence the adoption of sporting goods from consumer's perspective? Therefore, using Friedman test, the factors influencing consumer purchasing behavior are prioritized. Table 24 shows the priority of the factors affecting the adoption of sporting goods advertisement from a consumer perspective at different education levels.

\section{Table 24}

The priority of the factors affecting the adoption of sporting goods advertisement from a consumer perspective under different education levels.

\begin{tabular}{r|c|c|c|c|c|c|c|c}
\hline Row & Education & $\begin{array}{c}\text { Friedman } \\
\text { K2 }\end{array}$ & $\begin{array}{c}\text { Degree } \\
\text { of } \\
\text { Freedom }\end{array}$ & $\begin{array}{c}\text { Significance } \\
\text { Level }\end{array}$ & Priority 1 & Priority 2 & Priority $\mathbf{3}$ & $\begin{array}{c}\text { Priority } \\
\mathbf{1 2}\end{array}$ \\
\hline 1 & $\begin{array}{c}\text { Associate } \\
\text { of Art \& } \\
\text { Over }\end{array}$ & 268.566 & 11 & 0.0001 & $\begin{array}{c}\text { Celebrity } \\
\text { Availability }\end{array}$ & $\begin{array}{c}\text { Celebrity's } \\
\text { Use of } \\
\text { Product }\end{array}$ & Motivation & Popularity \\
\hline 2 & $\begin{array}{c}\text { BA \& } \\
\text { Over }\end{array}$ & 167.112 & 11 & 0.0001 & Credibility & $\begin{array}{c}\text { Celebrity } \\
\text { Availability }\end{array}$ & Motivation & Popularity \\
\hline
\end{tabular}

Question 5: what are the most effective and significant factors (in terms of marriage status in the current research) that can influence the adoption of sporting goods from consumer's perspective? Therefore, using Friedman test, the factors influencing consumer purchasing behavior are prioritized. Table 25 shows the priority of the factors affecting the adoption of sporting goods advertisement from a consumer perspective under single/married status.

\section{Table 25}

The priority of the factors affecting the adoption of sporting goods advertisement from a consumer perspective based on single/married status

\begin{tabular}{|c|c|c|c|c|c|c|c|c|}
\hline Row & $\begin{array}{c}\text { Marriage } \\
\text { Status } \\
\end{array}$ & $\begin{array}{c}\text { Friedma } \\
\mathrm{n} \mathrm{K2}\end{array}$ & $\begin{array}{l}\text { Degree of } \\
\text { Freedom }\end{array}$ & $\begin{array}{c}\text { Significan } \\
\text { ce Level }\end{array}$ & Priority 1 & Priority 2 & Priority 3 & Priority 12 \\
\hline 1 & Single & $\begin{array}{ll} & 28.32 \\
9 & \end{array}$ & 11 & 0.0001 & $\begin{array}{c}\text { Celebrity } \\
\text { Availability }\end{array}$ & Motivation & Credibility & Popularity \\
\hline 2 & Married & $4^{150.4}$ & 11 & 0.0001 & $\begin{array}{c}\text { Celebrity } \\
\text { Availability }\end{array}$ & $\begin{array}{c}\text { Celebrity } \\
\text { Availability }\end{array}$ & Motivation & Popularity \\
\hline
\end{tabular}

Question 6: is there a significant difference between the perspectives of different ages regarding the impact of celebrity endorsement of sporting goods on customer purchasing intention?

To compare the perspective of different ages regarding the impact of celebrity endorsement of sporting goods on customer purchasing intention, and given the normality of the variable in the group 3 , a comparison is made using Kruskal-Wallis test. Accordingly, the test's hypotheses are as follows. 
$\mathbf{H}_{\mathbf{0}}$ there is not a significant difference regarding the impact of celebrity endorsement of sporting goods on consumer purchasing behavior.

$\mathbf{H}_{\mathbf{1}}$ there is a significant difference regarding the impact of celebrity endorsement of sporting goods on consumer purchasing behavior.

Table 26

Descriptive findings relevant to the view of the respondents from different ages on the effect of celebrity endorsement of the sporting goods on consumer purchasing behavior

\begin{tabular}{c|c|c|c|c}
\hline Group & Mean & Standard Deviation & Min. & Max. \\
\hline Less than 20 Years & 3.08 & 0.51 & 1.05 & 4.74 \\
\hline $21-25$ & 3.32 & 0.7 & 1.07 & 4.83 \\
\hline $26-30$ & 3.01 & 0.69 & 1.43 & 4.19 \\
\hline $31-35$ & 2.84 & 0.64 & 1 & 3.76 \\
\hline Over 36 & 2.94 & 0.76 & 1.07 & 4.38 \\
\hline
\end{tabular}

Table 27

A comparison of the view of the respondents from different ages on the effect of celebrity endorsement of the sporting goods on consumer purchasing behavior

\begin{tabular}{c|c|c|c|c|c|c}
\hline Model & $\begin{array}{c}\text { Total } \\
\text { Squares }\end{array}$ & $\begin{array}{c}\text { Degree of } \\
\text { Freedom }\end{array}$ & $\begin{array}{c}\text { Mean } \\
\text { Square }\end{array}$ & $\begin{array}{c}\text { The } \\
\text { significance } \\
\text { level of } \\
\text { homogeneity } \\
\text { of variance } \\
\text { test }\end{array}$ & $\begin{array}{c}\text { Statistics } \\
\text { F }\end{array}$ & $\begin{array}{c}\text { Significance } \\
\text { Level }\end{array}$ \\
\hline Between Groups & 5.015 & 4 & 1.254 & 0.096 & 3.393 & 0.01 \\
\hline Within Groups & 126.734 & 343 & 0.369 & & & \\
\hline Total & $\mathbf{1 3 1 . 7 4 9}$ & $\mathbf{3 4 7}$ & &
\end{tabular}

As the results in Table 27 show, since the significance level for homogeneity of variance test is 0.096 , and is higher than 0.05 , the equality assumption of the variances is accepted. In addition, in ANOVA of some independent groups, statistics F is 3.393 and the test's significance level is 0.01 , which the significance number is less than 0.05 . Thus, at $\alpha=0.05$, the null hypothesis is rejected, and the opposite one is confirmed, indicating that there is a significant difference between the view presented by the respondents of the different ages regarding the impact of celebrity endorsement of sporting goods on consumer purchasing behavior.

Table 28

The results of LSD post hoc test to compare the views of the respondents with different ages about the effect of celebrity endorsement of the sporting goods on consumer purchasing behavior

\begin{tabular}{c|c|c|c}
\hline Group 1 & Group 2 & Significance Level & Result \\
\hline \multirow{3}{*}{ Less than 20 Years } & $21-25$ & 0.022 & Significant \\
\cline { 2 - 4 } & $26-30$ & 0.457 & Non-Significant \\
& $31-35$ & 0.039 & Significant \\
\hline \multirow{2}{*}{$21-25$} & Over 36 & 0.238 & Significant \\
& $26-30$ & 0.013 & Non-Significant \\
\cline { 2 - 4 } & $31-35$ & 0.205 & Non-Significant \\
\hline \multirow{2}{*}{$26-30$} & Over 36 & 0.613 & Significant \\
\hline \multirow{2}{*}{$31-35$} & $31-35$ & 0205 & Non-Significant \\
\hline
\end{tabular}


The results reveal that the effect of celebrity endoresment of sporting goods on consumers' purchasing behavior at ages 21 to 25 years is higher than other groups.

\section{DISCUSSION AND CONCLUSION}

The current article sought to explain the responses of the respondents to the celebrity availability in sporting goods advertising. Advertising plays a crucial role in growth and development of the brand image in the mind of customers. The body of research performed in this area confirms the direct and positive impact of such endorsements on customer's mind and purchasing intention. The customer's attitude toward the brand easily can be changed through celebrity availability. As mentioned in previous studies, the current research also underlines the celebrity availability in advertising and its positive impact on the target consumer's purchase intention. The consumers are commonly influenced by celebrities' attraction and credibility. However, celebrities' motivation and credibility has the greatest impact. In case of a good compatibility between product-celebrity, consumer purchasing intention can be significantly impacted.

The current research is effective both in terms of practice as well as theory. In theory, although this issue is consistent with previous research, it shows that the components related to the impact of celebrity availability in advertising on consumer purchasing behavior cannot be individually reviewed and analyzed without the intervention of demographic parameters. According to the results, the celebrity availability plays a critical role in an advertisement and is highly capable of changing the attitudes of consumers towards the product and motivate them to buy the product. Accordingly, when customers become more motivated to purchase a product due to the presence of celebrity, they have found more consistency between product attributes/brand, and celebrity personality dimensions. The present research is able to provide a better understanding of the methods of influencing the celebrity availability components on customers' behavior in different groups. From an experimental perspective, the findings of the current research will help marketing professionals and companies to use these results for their own marketing strategies, and to utilize different strategies for different groups.

\section{Limitations}

A part of the statistical population of students was composed of high school age students who access to them was highly challenging due to various constraints. The questionnaires were distributed only in the city of Mashhad. If the data are collected from different cities, more accurate and comprehensive results will be achieved. The sample size was normal, which must be increased to achieve a more comprehensive understanding of the respondents. Given the disproportionate number of women and men as the respondents, in case the percent of responding was near-equal, ranking results may be changed in terms of gender.

\section{Recommendations}

Future research should investigate the question: whether or not the media celebrities with entertaining qualities are more effective in advertising than sports celebrities? By combining cultural components, future research can analyze the effect of celebrity availability in advertising.

\section{References}

Abdolvand, M., Hoseinzadeh Emam, A. (2014). Evaluating and Prioritizing Effective Factors in Selecting Celebrity Endorsements for Advertising Campaigns from the Consumers' Point of View. Jounal of Marketing Management, 9(23), 19-40.

Adam, M. A., \& Hussain N. (2017). Impact of celebrity endorsement on consumers buying behavior. British Journal of Marketing Studies, 5(3), 79-121.

Agrawal, J., \& Kamakura, W. A. (1995). The Economic Worth of Celebrity Endorsers: An Event Study Analysis. Journal of Marketing, 59(3), 56. 
Ahmadi, S. A. A. Saleh, A, Faridi, M. R. (2011). Research Methodology in Management. Tehran: Amir Kabir Publications.

Ahmed, A., Azmat, F., Mir, \& Farooq, O. (2012). Effect of celebrity endorsement on customers' buying behavior: A perspective from Pakistan. Interdisciplinary Journal of Contemporary Research in Business. Institute of Interdisciplinary Business Research, 4(5), 584-592.

Alamolhodaei, S. M. A., \& Ardakani, M. F. (2015). Investigating the effective factors on entering into international markets by presenting the local Islamic model. Academic Journal of Economic Studies, 1(1), 22-34.

Ardakani, S. H. M., Ardakani, M. S., \& Ardakani, M. F. (2015). A study about customer satisfaction of eservice quality of point of sale (POS). Academic Journal of Economic Studies, 1(2), 120-131.

Arora, A., \& Sahu, K. (2014). Celebrity endorsement and its effect on consumer behavior. Internationa Journal of Retailing \& Rural Business Perspectives, 3(2), 866.

Ataman, B., \& B. Ulengin, (2003). A note on the effect of brand image on sales. J. Prod. Brand Manage, 12, 237-250.

Atkin, C., \& Block, M. (1983). Effectiveness of Celebrity Endorsers. Journal of Advertising Research, 23(1), 57-61.

Baker, M. J., \& Churchill Jr, G. A. (1977). The impact of physically attractive models on advertising evaluations. Journal of Marketing research, 14, 538-555.

Bedard, L. Jose, D., Marshal, L. (2002). Social psychology. 1st ed. Tehran: Savalan Publications.

Bush, A. J., Martin, C. A., \& Bush, V. D. (2004). Sports Celebrity Influence on the Behavioral Intentions of Generation. Journal of Advertising Research, 44(1), 108-118.

Danai, H. A., Ghezavat, F., \& Ardakani, M. F. (2018). The Effects of Intellectual Capital on firm Performance in Exporting Companies. Academy of Social Science Journal, 3(6), 1191-1198.

Debevec, K., Kernan, J.B. (1984). More Evidence on the Effects of a Presenter's Physical Attractiveness: Some Cognitive, Affective and Behavioral Consequences, In: Advances in Consumer Research, (Ed.) Thomas.

Erdogan, B. Z., (1999). Celebrity endorsement: A literature review. Journal of Marketing Management, 15(4), 291- 314.

Friedman, H. H., \& Friedman, L. (1978). Does the celebrity endorser's image spill over the product? Journal of the Academy of Marketing Science, 6, 291-299.

Ghanbari, S., Alizadeh, M. R., Eslamfard, F., \& Ardakani, M. F., (2015). Evaluation of the effective factors in historical- cultural tourism by structural equation modeling (SEM) (Case Study: Historic City of Farahabad). Journal of Geographic Space, 15(49), 189-211.

Goldsmith, R. E., Lafferty, B. A., \& Newell, S. J. (2000). The impact of corporate credibility and celebrity credibility on consumer reaction to advertisements and brands. Journal of Advertising, 29(3), 43-54.

Hergenhan, B. R. Olson, H. M. (2005). Learning theories. 6th ed. Tehran: Doran Publications.

Hoffner, C., \& Cantor, J. (1991). Perceiving and responding to mass media characters. In J. ryant \& D. Zillmann (Eds.). Responding to the screen: Reception and reaction processes (pp. 63-101). Hillsdale, NJ: Lawrence Erlbaum Associates, Inc.

Hovland, C.I., Lumsdaine. A.A., \& Sheffield, E.D. (1949). Experiments on Mass Communication. Princeton: Princeton University Press.

Kaikati, J. G. (1987). Celebrity advertising: a review and synthesis. International Journal of Advertising, 6(2), 93-105.

Kamins, M. A. (1990). An Investigation into the Match-Up-Hypothesis in Celebrity Advertising When Beauty be Only Skin Deep. Journal of Advertising, 19(1).4-13.

Khalatbari, M. J. (2007). Research method \& Statistics. 1st ed. Tehran: Pardazesh publications.

Kotler, F. (2006). Marketing management. Amokhteh Publications; Isfahan; 3rd edition.

McCracken, G. (1989). Who is the celebrity endorser? Cultural foundation of the endorsement process. Journal of Consumer Research, 16(3), 310-321. 
McGuire, W. J. (1968). Personality and attitude change: An information-processing theory. In A. G. Green-Wald, T. C. Brock, \& T. M. Ostrom (Eds.), Psychological foundations of attitudes (pp. 171-196). New York, NY: Academic Press.

Memar Nejad, H. 2012; http://memarnejad1300.blogfa.com.

Mowen, J. C., \& Minor, M. S. (2002). Consumer behavior. 1st ed. Nashere-An Publications.

Mowen, J. C., \& Minor, M. S. (2010). Consumer behavior. 1st edition.

Mozaheb, A., Alamolhodaei, S. M., \& Ardakani, M. F. (2015). Effect of Customer Relationship Management (CRM) on Performance of Small-Medium Sized Enterprises (SMEs) Using Structural Equations Model (SEM). International Journal of Academic Research in Accounting, Finance and Management Sciences, 5(2), 42-52.

Mukherjee, D. (2009). Impact of Celebrity Endorsements on Brand Image. SSRN Electronic Journal. http://doi.org/10.2139/ssrn.1444814.

Ohanian, R. (1991). The impact of celebrity spokesperson's perceived image on consumer's intention to purchase. Journal of Advertising Research, 31(1), 46- 52.

Petty, R. E., Cacioppo, J. T., \& Schumann, D. (1983). Central and peripheral routes to advertising effectiveness: The moderating role of involvement. Journal of Consumer Research, 10, 135-146.

Rajesh, S., Raj, G., Dhuvandranand, S. \& Kiran, D. (2019). Factors Influencing Customers' Attitude Towards SMS Advertisement: Evidence from Mauritius. Studies in Business and Economics, 14(2) 141-159.

Rezaeifar, H., \& Montazer Ataei, M. (2015). Qualitative and quantitative research methodology. Marandiz publications.

Saffarinia, M. Karimi, Y. (2005). The psychology of change in attitude and energy consumer behavior. Iran Journal of Energy, 9(3), 69-83.

Schlecht, C., (2003). Celebrities impact on branding, Center on Global Brand Leadership, Columbia: Columbia Business School.

Shahbazi, E. (2012). The effectiveness of celebrates in commercial advertising in Iran. MA thesis; Islamic Azad University, Central Branch.

Shimp, T. A. (2008). Advertising, promotion, and other aspects of integrated marketing communications. Eighth Edition, Cengage Learning, Canada.

Solomon, M. R. (2014). Consumer behavior: buying, having, and being. 1st edition. Tehran: Bazaryaby Publications.

Spielman, H. M. (1981). The celebrity sell: making it work. Marketing Times, 28, 13-14.

Sternthal, B., Dholakia, R., \& Leavitt, C. (1978). The Persuasive Effect of Source Credibility: Tests of Cognitive Response. Journal of Consumer Research, 4(4), 252-260.

Uma, S. (2002). Research methods in management. Institute for Higher Education Management and Planning, 110.

Vatandoust, A. R. (2008). Statistics in applied research. Mashhad: Ostad Publications.

Wei, P. S., \& Lu, H. P. (2013). An examination of the celebrity endorsements and online custom-er reviews influence female consumers' shopping behaviour. Computers in Human Behavior, 29(1), 193-201. 